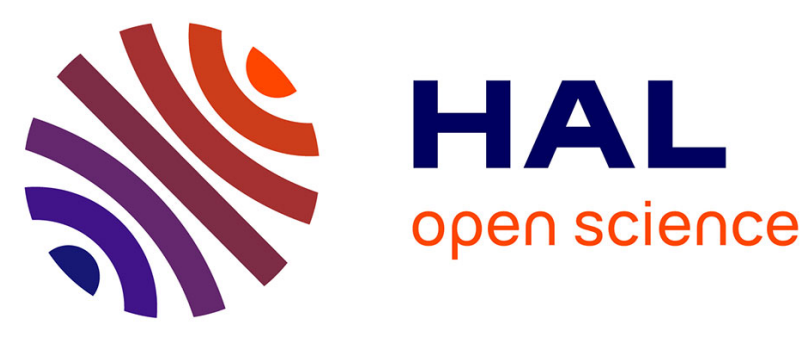

\title{
Structural and functional diversity of native brain neuronal nicotinic receptors
}

Cecilia Gotti, Francesco Clementi, Alice Fornari, Annalisa Gaimarri, Stefania

Guiducci, Irene Manfredi, Milena Moretti, Patrizia Pedrazzi, Luca Pucci, Michele Zoli

\section{To cite this version:}

Cecilia Gotti, Francesco Clementi, Alice Fornari, Annalisa Gaimarri, Stefania Guiducci, et al.. Structural and functional diversity of native brain neuronal nicotinic receptors. Biochemical Pharmacology, 2009, 78 (7), pp.703. 10.1016/j.bcp.2009.05.024 . hal-00509504

\section{HAL Id: hal-00509504 https://hal.science/hal-00509504}

Submitted on 13 Aug 2010

HAL is a multi-disciplinary open access archive for the deposit and dissemination of scientific research documents, whether they are published or not. The documents may come from teaching and research institutions in France or abroad, or from public or private research centers.
L'archive ouverte pluridisciplinaire $\mathbf{H A L}$, est destinée au dépôt et à la diffusion de documents scientifiques de niveau recherche, publiés ou non, émanant des établissements d'enseignement et de recherche français ou étrangers, des laboratoires publics ou privés. 


\section{Accepted Manuscript}

Title: Structural and functional diversity of native brain neuronal nicotinic receptors

Authors: Cecilia Gotti, Francesco Clementi, Alice Fornari, Annalisa Gaimarri, Stefania Guiducci, Irene Manfredi, Milena Moretti, Patrizia Pedrazzi, Luca Pucci, Michele Zoli

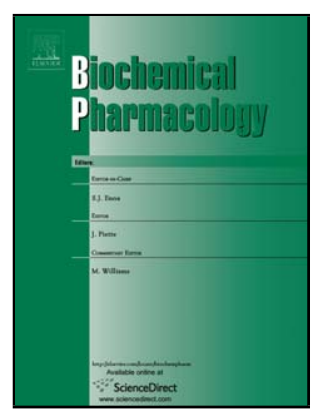

PII: S0006-2952(09)00435-3

DOI: doi:10.1016/j.bcp.2009.05.024

Reference: BCP 10197

To appear in: $\quad B C P$

Received date: $\quad 1-4-2009$

Revised date: 16-5-2009

Accepted date: $\quad$ 19-5-2009

Please cite this article as: Gotti C, Clementi F, Fornari A, Gaimarri A, Guiducci S, Manfredi I, Moretti M, Pedrazzi P, Pucci L, Zoli M, Structural and functional diversity of native brain neuronal nicotinic receptors, Biochemical Pharmacology (2008), doi:10.1016/j.bcp.2009.05.024

This is a PDF file of an unedited manuscript that has been accepted for publication. As a service to our customers we are providing this early version of the manuscript. The manuscript will undergo copyediting, typesetting, and review of the resulting proof before it is published in its final form. Please note that during the production process errors may be discovered which could affect the content, and all legal disclaimers that apply to the journal pertain. 


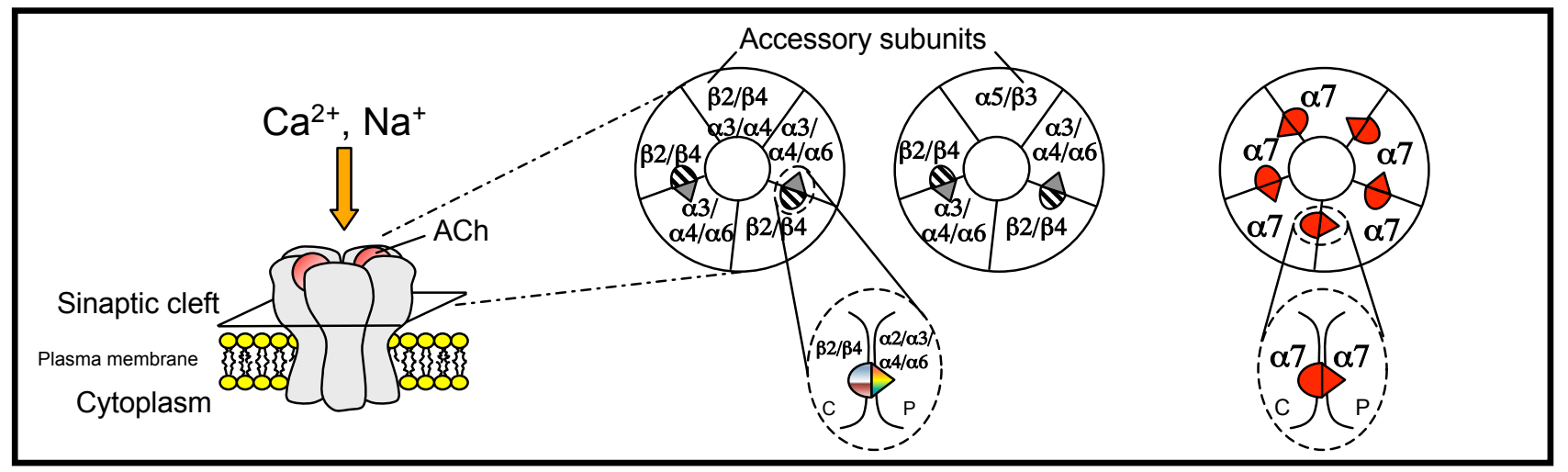




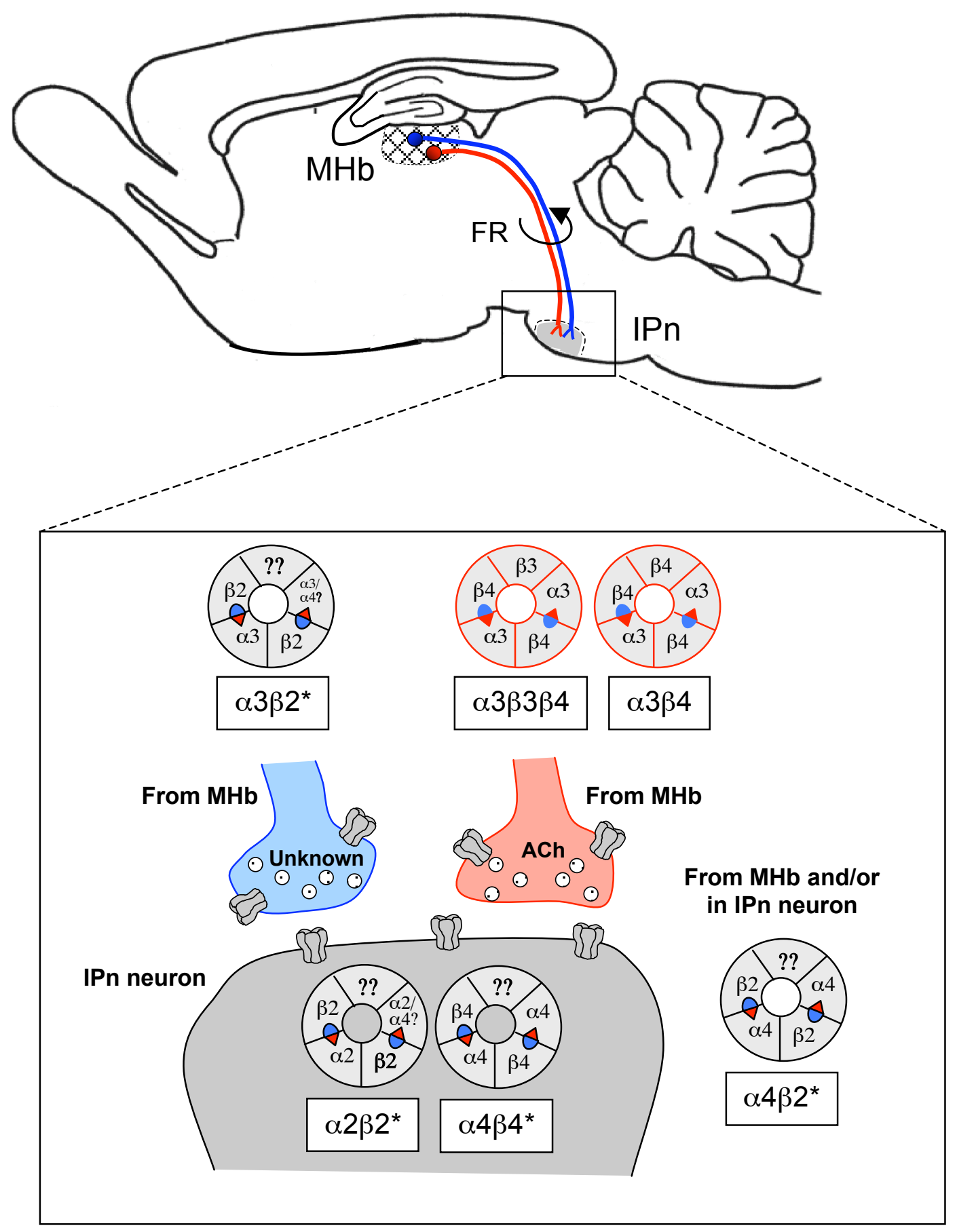




\section{SPECIAL ISSUE}

Neuronal Nicotinic Receptor-based Therapeutics

to be published in Biochemical Pharmacology

Editors: Daniel Bertrand, Murali Gopalakrishnan and Diana Donnelly-Roberts

\section{STRUCTURAL AND FUNCTIONAL DIVERSITY OF NATIVE BRAIN NEURONAL NICOTINIC RECEPTORS.}

Cecilia Gotti ${ }^{\mathrm{a}}$, Francesco Clementi $^{\mathrm{a}}$, Alice Fornari $^{\mathrm{b}}$, Annalisa Gaimarri ${ }^{\mathrm{a}}$, Stefania Guiducci $^{\mathrm{b}}$, Irene Manfredi ${ }^{\mathrm{a}}$, Milena Moretti ${ }^{\mathrm{a}}$, Patrizia Pedrazzi ${ }^{\mathrm{b}}$, Luca Pucci ${ }^{\mathrm{a}}$ and Michele Zoli $^{\mathrm{b}}$

${ }^{a}$ CNR, Institute of Neuroscience, Cellular and Molecular Pharmacology, Department of Medical Pharmacology, University of Milan, Milan, Italy. ${ }^{b}$ Department of Biomedical Sciences, Section of Physiology, University of Modena and Reggio Emilia, Modena, Italy

\section{Corresponding author:}

Dr. Cecilia Gotti ,

CNR, Institute of Neuroscience,

Cellular and Molecular Pharmacology Center,

Department of Medical Pharmacology

University of Milan

Via Vanvitelli 32, 20129 Milan, Italy

Tel +3902 50316974, Fax +39027490574

Email: c.gotti@in.cnr.it 


\begin{abstract}
Neuronal nicotinic acetylcholine receptors (nAChRs) are a family of ligand-gated ion channels present in the central and peripheral nervous systems, that are permeable to mono-and divalent cations. They share a common basic structure but their pharmacological and functional properties arise from the wide range of different subunit combinations making up distinctive subtypes.

nAChRs are involved in many physiological functions in the central and peripheral nervous systems, and are the targets of the widely used drug of abuse nicotine. In addition to tobacco dependence, changes in their number and/or function are associated with neuropsychiatric disorders, ranging from epilepsy to dementia.

Although some of the neural circuits involved in the acute and chronic effects of nicotine have been identified, much less is known about which native nAChR subtypes are involved in specific physiological functions and pathophysiological conditions.

We briefly review some recent findings concerning the structure and function of native nAChRs, focusing on the subtypes identified in the meso-striatal and habenulo-interpeduncular pathways, two systems involved in nicotine reinforcement and withdrawal. We also discuss recent findings concerning the effect of chronic nicotine on the expression of native subtypes.
\end{abstract}

Key words: neuronal nicotinic receptors, subtypes, subunit composition, stochiometry, meso-striatal pathway, habenulo-interpeduncular pathway 


\section{Introduction}

Nicotine is a major component of tobacco smoke whose behavioural effects are due to its interactions with a family of acetylcholine (ACh)-gated channels (nicotinic ACh receptors, nAChRs) present in the central and peripheral nervous systems [1-5]. These share a common basic structure but have specific pharmacological and functional properties that are due to the very different subunit combinations that make distinctive subtypes. nAChRs are not only permeable to monovalent $\mathrm{Na}^{+}$and $\mathrm{K}^{+}$ions, but also to $\mathrm{Ca}^{2+}$ ions, and their ability to alter intracellular $\left[\mathrm{Ca}^{2+}\right][6]$ by activating different downstream intracellular pathways plays a pivotal role in neuron signalling (reviewed in [7]).

Brain nAChRs have a very widespread and non-uniform distribution. The majority have a presynaptic and /or preterminal localisation where they modulate the release of almost all neurotransmitters, but some also have a somatodendritic post-synaptic localization [3, 4]. The activation of nAChRs can have opposite modulatory effects in the same circuit depending on where they are expressed (for instance on excitatory or inhibitory neurons) [3, 8]. nAChRs are involved in a wide range of physiological functions in the central and peripheral nervous system, and changes in their number and/or function are associated with a number of pathophysiological conditions.

The recent development of genetically engineered mice with the targeted deletion of specific subunits (knockout mice, Ko) or mutations in critical receptor domains (knockin mice, Kin), as well as Ko mice made to re-express nAChR subunits in selected brain regions by means of lentiviral vectors, has led to the in vivo identification of complex subtypes and allowed the study of individual subtypes in specific cells and complex neurobiological systems (reviewed in $[1,9-12])$.

As a number of comprehensive reviews have described the structure and function of nAChRs $[3-5,13,14]$, the aim of this article is to provide a short overview of some aspects that have been the object of recent studies: the composition and function of native nAChR subtypes, particularly those present in the mesostriatal and habenulo-interpeduncular pathways, and how they are modulated by chronic exposure to nicotine.

\section{Structure of the nAChR}

nAChRs form a heterogeneous family of subtypes consisting of five subunits arranged around a central pore whose variety is mainly due to the diversity of the possible combinations of the known nine $\alpha(\alpha 2-\alpha 10)$ and three $\beta(\beta 2-\beta 4)$ subunits [15]. Unlike the $\beta$ subunits, all nine $\alpha$ subunits have adjacent cysteines, analogous to cysteines 192-193 of the $\alpha$ subunit of muscle- 
type nAChRs [16]. The subunits have been cloned from neuron-like cells or cDNA libraries obtained from vertebrate brain, but it has recently been shown that some of them are expressed by non-neuronal cell types throughout the body and have various functions. However, the nAChRs expressed in non-neuronal tissues are beyond the scope of this review and interested readers are referred elsewhere [17-21].

Neuronal nAChRs belong to a large superfamily of homologous receptors, the so called Cys-loop ion channel receptors, which also include muscle-type nAChRs and GABAA, GABAC, glycine and serotonin $5 \mathrm{HT}_{3}$ receptors (reviewed in [16]). Recent crystallisation and structural determinations of $\mathrm{ACh}$ binding proteins (homopentameric soluble proteins whose affinity spectrum resembles that of homomeric $\alpha 7$ receptors) from Lymnaea stagnalis and Bulinus truncates snails [22, 23], and the saltwater mollusc Aplysia californica [24], have helped define the molecular details of the receptor binding sites. Moreover, the crystallisation of prokaryotic ligand-gated cation channels from the bacterium Erwinia chrysanthemi (ELIC) [25, 26] and the proton-opened pentameric ligand-gated ion channel homologue from the bacterium Gloeobacter violaceus (GLIC) have further helped to define the molecular details of the receptor structure [27].

Like all of the other members of this superfamily of ligand-gated ion channels, nAChR subunits have a relatively hydrophilic extracellular amino terminal portion that carries the $\mathrm{ACh}$ binding site and faces the synaptic cleft, followed by three hydrophobic transmembrane domains (M1-M3), a large intracellular loop, and then a fourth hydrophobic transmembrane domain (M4) (reviewed in [28]). The M1-M4 transmembrane domains are arranged in concentric layers around the central aqueous pore: the M2 domain lines the pore membrane, M1 and M3 shield M2 from the surrounding lipid bilayer, and M4 is the most exposed to lipids.

Upon agonist binding to pentameric nAChRs, the domains of each of the five subunits are rearranged in such a way as to open the central pore and allow ion flux through the channel for a few milliseconds, after which the receptor closes to a non-conducting state [29]. Chronic exposure to a low nicotine concentration (such as that present in the blood of smokers) leads to consistent receptor desensitisation which stabilises the receptor in a closed state that is unresponsive to agonists (reviewed in [30]).

Binding studies using radioactive ligands have allowed the identification of two principal classes of nAChRs in the central nervous system: one class binds nicotine and other nicotinic agonists with $\mathrm{nM}$ affinity but not $\alpha$ Bungarotoxin ( $\alpha$ Bgtx); the other binds nicotine and nicotinic agonists with $\mu \mathrm{M}$ affinity, and $\alpha$ Bgtx with $\mathrm{nM}$ affinity [2]. The pharmacological heterogeneity of the 
nAChRs revealed by these studies was since been confirmed and extended by means of the molecular cloning of a large family of genes coding multiple nAChR subunits, and studies of their expression in heterologous systems. The $\alpha$ Bgtx-sensitive receptors can be homomeric or heteromeric, and are made up of the $\alpha 7, \alpha 8, \alpha 9, \alpha 7-\alpha 8$, or $\alpha 9-\alpha 10$ subunits whereas the $\alpha$ Bgtxinsensitive receptors are heteromeric and consist of combinations of $\alpha(\alpha 2-\alpha 6)$ and $\beta(\beta 2-\beta 4)$ subunits [31].

Each heteromeric nAChR is arranged as a pinwheel and has two agonist binding sites .i.e. hydrophobic pockets formed at the interface between two adjacent subunits that respectively contribute a primary and a complementary face [32]. Each subunit is asymmetric, and carries the primary and complementary face on opposite sides. The primary face is carried by the $\alpha 2, \alpha 3$, $\alpha 4, \alpha 6, \alpha 7, \alpha 8$ or $\alpha 9$ subunits (which have two adjacent cysteines), and contributes three loops from discontinuous sections of the primary sequence; the complementary face is carried by the $\beta 2, \beta 4, \alpha 7, \alpha 8, \alpha 9$, or $\alpha 10$ subunits and also contributes three discontinuous loops. The $\alpha 10$ subunit has been classified as an $\alpha$-type subunit, but is cannot act as a primary subunit at the agonist binding site, and only works when it is associated with the $\alpha 9$ subunit $[32,33]$. Similarly, $\alpha 5$ is not a true $\alpha$ subunit (see below). In general, the identical nature of hydrophobic residues of the primary component determines ligand binding affinity, whereas the residues contributed by the complementary component determine ligand selectivity [4].

Homomeric $\alpha 7, \alpha 8$ or $\alpha 9$ receptors have five binding sites to which the same subunit contributes both the primary and complementary components present on opposite sites of the same subunit [31].

\section{Role of non ligand-binding site (accessory) subunits in pentameric receptors}

In heteromeric $\alpha \mathrm{Bgtx}$-insensitive receptors, the accessory subunits are those that do not directly participate in forming the binding site. Heterologous expression studies have shown that the $\alpha 5$ and $\beta 3$ subunits only form functional channels when they are co-expressed with a principal and a complementary subunit $[34,35]$, thus indicating that they can only function as accessory subunits, whereas the $\alpha 3$ or $\alpha 4$ and $\beta 2$ or $\beta 4$ subunits can form ligand binding sites or assemble in the accessory position to produce receptors with different stoichiometries $[4,31,36]$. The role of accessory subunit has been investigated in the $\alpha 4 \beta 2 *^{1}$ subtypes in which the presence of different accessory subunits $(\alpha 5, \beta 3, \alpha 4, \beta 2)$ changes their pharmacological and biophysical properties, their sensitivity to allosteric modulators and their sensitivity to up-regulation [37-40].

\footnotetext{
${ }^{1}$ The native subtypes are identified by their known subunits; if these are followed by an asterisk, it means that other unidentified subunits may also be present.
} 
The $(\alpha 4 \beta 2)_{2} \alpha 5$ subtype has the highest $\mathrm{Ca}^{2+}$ permeability, whereas the $(\alpha 4 \beta 2)_{2} \beta 2$ subtype has the greatest affinity for $\mathrm{ACh}$ and nicotine activation, and is also the most sensitive to nicotine desensitisation [37]. Moreover, the presence of the $\alpha 5$ subunit in the $\alpha 4 \beta 2 *$ subtype confers sensitivity to the allosteric modulator galantamine [37]. The inclusion of the $\alpha 5$ subunit also affects the pharmacological and functional properties of other subtypes: for example in the $\alpha 3 \beta 2 *$ and $\alpha 3 \beta 4 *$ subtypes, it increases desensitisation and $\mathrm{Ca}^{2+}$ permeability, and alters agonist-stimulated responses [39].

It has been shown that the $\beta 3$ subunit co-assembles with several nAChR subunit combinations but, in all cases other than $\alpha 3 \beta 3 \beta 4$, it appears to have a dominant negative effect that leads to the absence of the functional expression of the assembled $\beta 3 *$ receptor complex [41, 42]. However our ex-vivo studies [31] indicate the great propensity of $\beta 3$ to assemble with $\alpha 6$ subunit, and $\alpha 6^{*}$ receptor expression in $\beta 3$ knock-out mice is decreased in the cell bodies and nerve terminals of dopaminergic neurons. This decrease suggests that the $\beta 3$ subunit is important for the formation of the majority of $\alpha 6 \beta 2 *$ or $\alpha 4 \alpha 6 \beta 2 *$ receptors, and that its loss causes defects in nAChR assembly, degradation and/or trafficking. The exclusive role of the $\beta 3$ subunit as an accessory subunit has been confirmed using fluorescently labelled $\alpha 6$ and $\beta 3$ subunits and the FRET technique, which has shown that only a single $\beta 3$ subunit is incorporated in pentameric $\alpha 6 \beta 2 *$ receptors[43].

\section{Subunit stoichiometry}

As nAChRs are pentameric, they can show considerable molecular diversity. In addition to the differences in subunit composition, some receptor subtypes may have the same subunit composition but different subunit stoichiometries.

Two different methodological approaches have shown that heterologously expressed $\alpha 4 \beta 2$ subtypes have an $(\alpha 4)_{2}(\beta 2)_{3}$ stoichiometry that is highly sensitive to activation by ACh [44, 45]. Subsequently it has been found that the $\alpha 4 \beta 2$ subtype has biphasic ACh concentration-effect curves in heterologous expression systems [38, 46, 47]. Changes in the ratio of $\alpha 4$ to $\beta 2$ subunits alter agonist sensitivity. The cells receiving excess $\alpha 4$ subunits are less sensitive to ACh (EC50 $100 \mu \mathrm{M})$. whereas those receiving excess $\beta 2$ subunits are more sensitive $(\mathrm{EC} 50 \approx 1 \mu \mathrm{M})$. The injection of mRNAs encoding linked $\alpha 4 \beta 2$ subunits with mRNA encoding $\beta 2$ or $\alpha 4$ generates $\mathrm{ACh}$ concentration-effect curves indicating respectively higher or lower ACh sensitivity [48]. These results strongly support the hypothesis that variations in $\alpha / \beta$ stoichiometry generate molecular subtypes with distinctive physiological and pharmacological characteristics. Furthermore, these different stoichiometries also have different $\mathrm{Ca}^{2+}$ permeability [39]. 
It has been shown that a number of brain regions contain a substantial number of low affinity $\beta 2 *$ epibatidine binding sites that may represent native $(\alpha 4)_{3}(\beta 2)_{2}$ receptors [49]. In addition, recent functional and biochemical studies have shown that cortical and thalamic nAChRs in heterozygous $\alpha 4^{+/-}$and $\beta 2^{+/-}$mice have different relative expressions of $\alpha 4$ and $\beta 2$ subunits, and that this correlates with differences in the functional properties of native nAChRs [50]. Overall, these findings support the conclusion that $\alpha 4 \beta 2 \mathrm{nAChRs}$ with different stoichiometries are expressed in native tissue.

Finally, different receptor stoichiometries may play a relevant role in pathophysiological states. Studies of transfected cells have shown that chronic exposure to nicotine upregulates the expression of $(\alpha 4)_{2}(\beta 2)_{3}$ stoichiometry and normalises the intracellular subunit stoichiometry of nAChRs carrying mutations linked to autosomal dominant nocturnal frontal lobe epilepsy [51].

\section{5. nAChR subtype assembly}

Expression studies using heterologous systems have shown that nAChR assembly is a tightly regulated and ordered process, which requires appropriate subunit-subunit interactions and perhaps other proteins (chaperones) that can assist receptor assembly [52, 53]. Vertebrate nAChR subunits may co-assemble in many possible combinations, and many more subtypes have been heterologously expressed than those identified in vivo. It seems that native nAChRs are assembled into functional pentamers with a relatively restricted number of subunit combinations [14].

In neurons, the first limitation on subunit assembly is, the cell-specific expression of subunits, but other factors play important roles, such as the influence of chaperone molecules, relative subunit concentrations, and intrinsic affinities between pairs of subunits. For example, the $\alpha 7$ subtype is mainly a homomeric receptor in neurons that co-express other subunits, but can form heteromeric receptors made up of the $\alpha 7$ subunit with the $\beta 3, \alpha 5$ and $\beta 3$ subunits in heterologous expression systems $[41,54,55]$.

An additional level of complexity when comparing native and heterologously expressed subtypes is that $\mathrm{nAChRs}$ behave differently in different cell contexts [56]. It seems that there are receptorspecific assembly folding factors for different steps in the assembly of the different subtypes present in some mammalian cell lines [57]. Different cell lines infected with adenoviruses encoding the $\alpha 7, \alpha 4$ and $\beta 2$ subunits produce the appropriate mRNA, but have very different levels of $\alpha 7$ and $\alpha 4 \beta 2$ subtype expression, furthermore, the ratio between surface and intracellular receptors may be very different in the same subtype. On the other hand, nAChRs made up of four different subunits have been detected in some brain regions but this complex 
subunit composition is difficult to obtain in heterologous systems, possibly because they lack the appropriate factors necessary for correct assembly.

\section{Native nAChR subtypes}

Important contributions to the identification of native nAChRs in the brains of rats and wildtype, Ko and Kin mice have been made using biochemical, immunoprecipitation and immunopurification techniques. It is now well established that the most abundant nAChR subtypes in the nervous system are homomeric $\alpha 7$ receptors and heteromeric receptors containing only one type of $\alpha$ and one type of $\beta$ subunit $[2,4]$. The $\alpha 4 \beta 2 *$ receptors account for $90 \%$ of the high affinity neuronal nAChRs in mammalian brain whereas the $\alpha 3 \beta 4 *$ subtype is predominant in the autonomic ganglia and adrenal medulla, as well as in subsets of neurons in the medial habenula, nucleus interpeduncularis, dorsal medulla, pineal gland and retina, although a certain proportion of $\alpha 3 \beta 4 *$ receptors in these tissues also contain accessory subunits.

In agreement with data obtained from studies using recombinant nAChRs, ex vivo studies have shown that brain nAChRs can contain more than two types of $\alpha$ subunit: for example, approximately $20 \%$ of $\alpha 4 \beta 2 *$ nAChRs also contain the $\alpha 5$ subunit, which is widespread in the brain [58]. Deletion of the $\alpha 5$ subunit reduces the high affinity agonist activation of presynaptic nAChRs in the striatum and thalamus without altering their number, and these results indicate that the primary effect of $\alpha 5$ incorporation is to increase $\mathrm{nAChR}$ function without affecting nAChR expression, which may explain why $\alpha 5$ Ko mice are less sensitive to the acute effects of nicotine administration $[59,60]$.

Besides the widespread $\alpha 4 \beta 2 *$ and more restricted $\alpha 3 \beta 4 *$ subtypes, other native subtypes have been recently identified in specific brain regions.

In situ hybrydisation studies have shown that the $\alpha 2 \beta 2 *$ subtype is highly expressed in many regions of primate brain $[61,62]$, whereas its expression in rodents is limited to retina and interpeduncular nucleus (IPn) [63, 64].

\section{1. $\alpha 6 \beta 3 *$ subtypes in mesostriatal and visual pathways}

Early in situ hybridisation studies showed that mRNAs for the $\alpha 6$ and $\beta 3$ subunits co-localise in the soma of dopaminergic cells of the mesostriatal pathway and retina, whereas the medial habenula $(\mathrm{Hb})$ contains only $\beta 3$ mRNA in large amounts $[65,66]$. Biochemical, ligand binding and functional assays, and immunopurification procedures using subunit specific antibodies, have shown that the striatum (a region that receives nerve terminals from midbrain dopaminergic 
cells) and the superior colliculus and lateral geniculate nucleus (two retina target regions) have $\alpha 6 \beta 2 \beta 3 *$ receptors that consist of the $\alpha 6 \beta 2 \beta 3$ and $\alpha 4 \alpha 6 \beta 2 \beta 3$ subtypes $[13,67]$.

The two ACh binding sites are identical in the $\alpha 6 \beta 2 \beta 3$ subtype, but different in the $\alpha 4 \alpha 6 \beta 2 \beta 3$ subtype, which has both an $\alpha 6 \beta 2$ and an $\alpha 4 \beta 2$ interface [67]. Purely $\alpha 6 \beta 2 \beta 3$ or mixed $\alpha 4 \alpha 6 \beta 2 \beta 3$ receptors have different pharmacological and physiological properties, and their cell biology may also be different. The $\alpha 4 \alpha 6 \beta 2 \beta 3$ subtype has higher affinity for nicotinic agonists than $\alpha 6 \beta 2 \beta 3$ [68], and chronic nicotine [69] has opposite effects on the expression of these subtypes in the striatum.

The $\alpha 6 \beta 2 *$ receptors are localised presynaptically in both visual and mesostriatal pathways and, together with the $\alpha 4 \beta 2 *$ subtype, modulate the release of dopamine from dopaminergic terminals in the striatum. Both receptor populations have indistinguishable binding affinities for various classical nicotinic agonists and antagonists, but different binding affinities and sensitivities for $\alpha$ conotoxin MII, which recognizes only $\alpha 6 \beta 2$ interfaces with $\mathrm{nM}$ affinity [67].

The mesostriatal dopamine (DA) pathway is a major brain target for nicotinic agonists and has two principal components : the ventral mesolimbic pathway, which has cell bodies in the ventral tegmental area (VTA), and terminals in the nucleus accumbens (nAc) and tuberculum olfactorium (TO); and the dorsal nigrostriatal pathway, which has cell bodies in the substantia nigra $(\mathrm{SN})$ and terminals in the caudate-putamen $(\mathrm{CPu}) . \mathrm{nAChRs}$ in the dopaminergic neurons of the mesostriatal pathway play an important role in controlling locomotion and the development of some long-lasting adaptations associated with nicotine abuse. Behavioural and functional studies of rats, nicotinic subunit $\beta 2$ Ko mice, and $\beta 2$ Ko mice selectively re-expressing the $\beta 2$ and/or $\alpha 6$ subunits in the ventral midbrain [70] [71] have shown that nAChRs in the dopaminergic neurons of the VTA are necessary for the rewarding effects of nicotine. Moreover, locomotion studies of $\beta 2$ Ko mice have shown that an imbalance in DA neurotransmission makes them hyperactive in the open field [72], and that selective re-expression of the $\beta 2$ subunit in the SN rescues this effect. Other studies of mice expressing hypersensitive $\alpha 6^{*}$ receptors have shown that their activation in DA neurons finely tunes DA release and is sufficient to cause hyperactivity [73].

Unpublished data from our laboratories show that the subunit composition of $\alpha 6^{*}$ receptors in the different subsystems of mesostriatal DA neurons are partially heterogeneous. The DA terminals of the nigrostriatal pathway exclusively express $\alpha 4 \alpha 6 \beta 2 \beta 3$ receptors, whereas 
those of the mesolimbic pathway express a majority of $\alpha 6 \beta 2 \beta 3$ receptors. In addition, a minor population of $\alpha 4 \beta 2 \beta 3$ receptors is only expressed in the $\mathrm{CPu}$. The fact that most of the receptors with two $\alpha 6 \beta 2$ interfaces are found in the ventral striatum, and that the dorsal striatum expresses only receptors with mixed $\alpha 4 \beta 2$ and $\alpha 6 \beta 2$ interfaces may partially explain recent evidence indicating the dominance of purely $\alpha 6^{*}$ sensitive responses in the nAc, and predominantly $\alpha 4$ responses in the $\mathrm{CPu}$ [74]. Furthemore, binding studies in striatal tissue have shown that $\alpha 4 \alpha 6 \beta 2 \beta 3$ is the subtype that is preferentially vulnerable to nigrostriatal damage as it is lost in the striatum of animal models of Parkinson's disease and human patients [75] .

\section{2. nAChRs in the habenulo-interpeduncular pathway}

As mentioned above, the addictive properties of nicotine are mainly due to the interaction of nicotine with the $\beta 2 *$ receptors present in the VTA and the induction of increased DA levels in the NAc. Recent studies have shown that the somatic manifestations of nicotine withdrawal are due to nAChRs containing the $\beta 4$ or $\alpha 5$ or $\alpha 2$ subunits in the habenulo-interpeduncular pathway ( $\mathrm{Hb}-\mathrm{IPn})[76,77]$. The $\mathrm{Hb}$ is a diencephalic structure that receives substantial input from multiple parts of the limbic system, and communicates with the IPn by means of the fasciculus retroflexus. Components of the Hb-IPn system are involved in the physiology and pathophysiology of reward phenomena [78, 79], and subserve a variety of behaviours such as learning and memory, nociception, stress, sleeping and eating.

Both $\mathrm{Hb}$ and IPn express variable levels of all known heteromeric nAChR subunit mRNAs, and the highest level of nAChRs in the CNS. Biochemical and immunoprecipitation studies have confirmed the heterogeneity of the nAChR subtypes expressed in the Hb-IPn pathway, and found that rat and mouse $\mathrm{Hb}$ and $\mathrm{IPn}$ contain two major and distinct populations of $\beta 2^{*}$ and $\beta 4^{*}$ receptors [64]. The $\beta 2 *$ population in the $\mathrm{Hb}$ contains the $\alpha 4 \beta 2 *$ and $\alpha 3 \beta 2 *$ subtypes, some of which also contain the accessory $\alpha 5$ or $\beta 3$ subunits. In the IPn, $\beta 2 *$ nAChRs exist as three populations of approximately equal size: $\alpha 2 \beta 2 *, \alpha 3 \beta 2 *$ and $\alpha 4 \beta 2 *[64]$.

In agreement with binding studies [80-82], our immunoprecipitation studies found that the $\beta 4 * \mathrm{nAChR}$ population in both regions is mainly associated with the $\alpha 3$ subunit, and a significant fraction of the $\alpha 3 \beta 4 *$ nAChRs contain accessory, mostly $\beta 3$ subunits. The $\beta 3$ subunits are associated with $\alpha 6 \beta 2 * \mathrm{nAChR}$ in the mesostriatal dopaminergic and visual pathways $[67,83]$ but the presence of $\beta 3$ subunits not associated with $\alpha 6$ subunits in the Hb-IPn pathway is in line with the findings of in situ hybridisation studies showing high levels of $\beta 3$ but not $\alpha 6$ subunit mRNA in the $\mathrm{Hb}[65,66,84]$. This is a novel subtype because ganglionic 
$\alpha 3 \beta 4{ }^{*}$ nAChRs contain $\alpha 5$ as an accessory subunit [85]. $\beta 3$ subunit mRNA is not expressed in the IPn [66] and so nAChRs containing $\beta 3$ cannot be synthesised in the IPn.

Among the subtypes present in the Hb-IPn pathway, only the $\alpha 3 \beta 4$ and $\alpha 3 \beta 3 \beta 4$ subtypes mediate $\left[{ }^{3} \mathrm{H}\right]$-ACh release in mouse IPn. The deletion of the $\beta 3$ subunit gene does not affect the level of expressed subtypes in the $\mathrm{Hb}$, but decreases the number of $\alpha 3$ and $\beta 4$ subunits in the IPn by $\sim 50 \%$, and similarly decreases the $\left[{ }^{3} \mathrm{H}\right]$-ACh release in mouse IPn with no obvious change in $\mathrm{EC}_{50}$. This underlines the fact that, as has been suggested in the case of the $\alpha 6 \beta 2 \beta 3 *$ receptors in the visual and mesostriatal pathways, the $\beta 3$ subunit may play a targeting role in the $\mathrm{Hb}[13,37]$.

The role of the other subtypes in the Hb-IPn system is difficult to establish, but studies of $\mathrm{Rb}^{+}$efflux from IPn synaptosomes indicate that $\beta 2 * n$ AChRs are functional [64]. These receptors are not involved in $\mathrm{ACh}$ release, and may modulate the release of other neurotransmitters in non-cholinergic inputs to the $\operatorname{IPn}[86,87]$.

In $\mathrm{Hb}$ synaptosomes, $\mathrm{Rb}^{+}$efflux indicates that $\beta 2^{*} \mathrm{nAChRs}$ may be the only functional presynaptic subtype [64] and may mediate the release of several neurotransmitters as dopaminergic [88], GABA, glutamatergic [89] and noradrenergic terminals [90] have all been identified in this nucleus.

The IPn contains $\alpha 2 \beta 2 *, \alpha 3 \beta 2 *$ and $\alpha 4 \beta 2 *$ nAChRs. The $\alpha 2 \beta 2 *$ nAChRs are expressed by intrinsic IPn neurons because $\alpha 2$ mRNA is only expressed by the IPn [91]. The $\alpha 3 \beta 2 *$ nAChRs may only be located presynaptically as $\alpha 3 \mathrm{mRNA}$ is not expressed by intrinsic neurons, whereas $\alpha 4 \beta 2 *$ nAChRs may be expressed on intrinsic IPn neurons and/or afferents to the IPn, and may therefore have both pre- and postsynaptic locations (see lower part figure 1).

In conclusion the essential role of $\alpha 3 \beta 4$ and $\alpha 3 \beta 4 \beta 3$ in mediating ACh release has been established (see figure 1) but many more studies using different approaches are necessary to define the cellular and subcellular localisation and function of all of the subtypes identified in the $\mathrm{Hb}-\mathrm{IPn}$ pathway.

\subsection{Homomeric and heteromeric $\alpha 7$ receptors}

Homomeric $\alpha 7$ receptors are the most widely expressed $\alpha$ Bgtx-binding receptors in mammalian brain, particularly in the cortex, hippocampus and subcortical limbic regions, and (at low levels) in the thalamic regions and basal ganglia. These $\alpha 7$ receptors may have a presynaptic localisation where they are involved in the direct release of glutamate in the hippocampus and VTA, and of excitatory amino acid in the prefrontal cortex [92], or the indirect release of DA from striatum and prefrontal cortex, and noradrenaline from the hippocampus [93-95]) or a 
postsynaptic or somatic localisation, where their high $\mathrm{Ca}^{2+}$ permeability can have long-term effects on metabolic pathways and gene expression.

$\alpha B g t x$ receptors have been affinity purified from the brain of various species, and are pentamers with a single $\alpha 7$ subunit in rat and chick, and homomeric $\alpha 8$ or $\alpha 7-\alpha 8$ receptors in chick [14]. Studies using heterologous systems have shown that the $\alpha 7$ subunit can also form functional channels with the $\alpha 5, \beta 2$ or $\beta 3$ subunits $[41,54,55]$. Its particular association with the $\beta 2$ subunit leads to the expression of an $\alpha 7 \beta 2$ receptor with distinct pharmacological and functional properties $[41,54,55]$. It has recently been shown that the $\alpha 7$ and $\beta 2$ subunits are coexpressed in rat basal forebrain cholinergic neurons and form a novel heteromeric $\alpha 7 \beta 2$ subtype [96]. This subtype has different biophysical and pharmacological properties from those of the homomeric $\alpha 7$ receptors expressed by VTA neurons and is highly sensitive to functional inhibition by oligomeric forms of amyloid $A \beta 1-42$. Characterisation of the $\alpha 7 *$ receptors present in the forebrain cholinergic neurons of $\beta 2$ Ko mice has further confirmed that the expressed $\alpha 7 \beta 2$ subtype has different biophysical and pharmacological properties from those of wild-type basal forebrain neurons, thus indicating that the $\alpha 7 \beta 2$ subunits probably assemble to form a new subtype in the former [96].

\section{Regulation of native subtypes by chronic nicotine exposure}

Chronic nicotine exposure gives rise to neural adaptations that change whole cell physiology and behaviour, mainly due to its interaction with nAChRs.

The effects of nicotine may be due to nAChR activation or desensitisation because, also in the latter case, nicotine can alter neuronal function by interrupting the transmission of endogenous $\mathrm{ACh}[30$, 97]. As nAChR subtypes are not equally responsive to nicotine activation and desensitisation, this can influence their functional and behavioural responses (reviewed in [30, 97]). In particular, it has been shown that the $\alpha 7$ subtype is more susceptible to inactivation than the $\beta 2 *$ or $\beta 4 *$ subtypes, but it is not yet clear whether the same subtype may be differently sensitive to activation depending on its pre- or post-synaptic localisation and/or the cell on which it is expressed.

Studies of the brains of tobacco smokers and animals chronically exposed to nicotine have shown that long-term exposure often triggers an increase in the number of nAChRs (so called upregulation) [98], and the fact that there is no increase in $\alpha 2, \alpha 3, \alpha 4, \alpha 5$ or $\beta 2$ mRNA levels in mouse brain chronically exposed to nicotine suggests that post-transcriptional mechanisms are responsible for this [99]. Moreover, nAChR up-regulation is independent of the cells on which the receptors are expressed: i.e., it is "cell autonomous" [100]. 
In vitro studies of cells transfected with $\mathrm{nAChR}$ subtypes have shown the nicotineinduced up-regulation of homomeric $\alpha 7$, and various heteromeric $\alpha 3 \beta 2, \alpha 4 \beta 2, \alpha 6 \beta 2$ and $\alpha 3 \beta 4$ receptors [101] [102, 103], and in vivo studies of animals chronically treated with nicotine and the brains of human smokers have shown that the most up-regulated receptor is the $\alpha 4 \beta 2$ subtype [104]. This up-regulation has been mainly measured by binding studies using membrane permeable ligands that bind both intracellular and surface receptors, and have been performed at nicotinic ligand concentrations in the $\mathrm{Kd}$ range that mainly bind the desensitised inactive state of the receptors (see [30] and references therein). Binding studies using membrane impermeant ligands have shown that approximately $85 \%$ of the receptors in transfected cells and neurons are intracellular [105] [106], and that chronic nicotine treatment increases both intracellular and surface receptors [15].

Various mechanisms have been hypothesised in order to explain $\alpha 4 \beta 2$ subtype up-regulation, including increased receptor assembly, decreased surface turnover, increased surface receptor traffic, decreased receptor degradation, and an induced conformational switch into high affinity receptors that become activated more easily (reviewed in $[15,30,106])$. Recent data have shown that the presence of the $\alpha 5$ subunit makes the $\alpha 4 \beta 2$ subtype in rat hippocampus, striatum, cerebral cortex and thalamus resistant to up-regulation in vivo [107].

The effect of chronic nicotine exposure on other nAChR subtypes is less well established. The $\alpha 7$ receptors, which have lower nicotine affinity, are up-regulated to a lesser extent than the $\alpha 4 \beta 2$ subtype and in only a few regions [108]. The $\alpha 3 \beta 4 *$ subtype, which is prominent in the pineal gland, $\mathrm{Hb}$, IPn and autonomic ganglia, seems to be resistant to up-regulation [104].

A number of studies have tried to correlate the increase in receptors following chronic nicotine exposure with a possible increase in $\mathrm{nAChR}$ function. After nicotine exposure, oocyte-expressed $\alpha 4 \beta 2$ receptors reduce $\mathrm{ACh}$-induced currents, whereas the same receptors expressed in mammalian cell lines show increase in these currents and are more sensitive to ACh than controls (reviewed [97]) .

Chronic exposure to nicotine of the $\alpha 7$ and $\alpha 3$ subtypes in oocytes, leads to the almost total functional inactivation of the $\alpha 7$ receptors, but only partial inactivation of the $\alpha 3$ subtype, [109]. On the contrary, in cultured cortical neurons, there is an increase in the number of $\alpha 7$ receptors and the whole cell response, with no evidence of long-lasting desensitisation even after long-term nicotine exposure [110].

Nicotine can activate and regulate several subtypes involved in the presynaptic release of various neurotransmitters, and chronic nicotine treatment can differently affect these different 
subtypes [110]: for example it has been reported that the subtypes involved in the release of dopamine may be functionally increased [111], decreased [112] or unaffected [113].

In conclusion, the data concerning in vivo $\mathrm{nAChR}$ function after chronic exposure to nicotine are contradictory insofar as they depend on the subtype, the cell systems expressing the subtype, and the functional assays used to measure the activity of the nAChRs.

Much attention has recently been given to $\alpha 6^{*}$ receptors, which bind aconotoxin MII. Rodent studies have shown that intravenous nicotine self-administration leads to an increase in the number of $\alpha 6^{*}$ receptors in rats [114], but a decrease in the number of striatal $\alpha 6^{*}$ receptors in rodents chronically treated with nicotine by means of minipumps $[115,116]$ or receiving it in drinking water [117]. These apparently discrepant results may be due to the different modalities of nicotine administration leading to differences in nicotine concentration in the brain and/or the kinetics or duration of receptor exposure, which may differently affect $\alpha 6^{*} \mathrm{nAChRs}$. The results of a recent experiment has added further complexity. It was found that the decrease in overall aconotoxinMII binding observed after oral nicotine administration is due to two opposite effects on different $\alpha 6^{*}$ subtypes: a decrease in the $\alpha 4 \alpha 6 \beta 2 *$ subtype and an increase in the $\alpha 6$ (non $\alpha 4) \beta 2 *$ subtype [118]. Accordingly, a4-/- mice chronically treated with oral nicotine show increased aconotoxinMII binding in striatum [118].

As mentioned above, the $\alpha 4 \beta 2 *$ and $\alpha 6 \beta 2 *$ subtypes are the main subtypes modulating dopamine release in rodent striatum. Ex vivo, studies have shown that $\alpha 6 \beta 2 *$ receptors mediate $30-50 \%$ of ${ }^{3} \mathrm{H}$-dopamine release in the $\mathrm{CPu}$ and nAc [71], and voltammetry studies indicate that they are responsible for most of the dopamine release in the nAc obtained with the burst stimulation of striatal slices [74]. Chronic oral nicotine treatment, which up-regulates the $\alpha 6$ (non- $\alpha 4$ ) $\beta 2$ subtype but leads to the loss of $\alpha 4 \alpha 6 \beta 2$, abolishes $\alpha 6^{*}$ mediated effects on burst firing, thus suggesting that is the former subtype that primarily modulates this type of $\alpha 6 \beta 2 *$ mediated dopamine release [118].

Studies of non-human primates have shown that, although both $\alpha 4 \beta 2$ and $\alpha 3 / \alpha 6 \beta 2 *$ subtypes are present at similar levels in monkey striatum, the latter determines $70 \%$ of the dopamine release. Long-term nicotine treatment selectively modifies dopamine release in distinct striatal sub-regions: i.e. ventral but not the dorsal putamen [119]. The same treatment upregulates $\alpha$ conotoxinMII-resistant ${ }^{125}$ I-epibatidine binding (putative $\alpha 4 \beta 2 *$ receptors) whithout changing ${ }^{125}$ I- $\alpha$ conotoxinMII binding ( $\alpha 3 / \alpha 6 \beta 2 *$ receptors) in both the dorsal and the ventral putamen. It would be interesting to assess whether the regional heterogeneity in nicotine- 
mediated dopamine release stems from alterations in $\alpha 6^{*}$ composition, as has been shown in rodents.

Although chronic nicotine exposure decreases the number of $\alpha 6^{*}$ receptors in the striatum, it has no effect on those in the superior colliculus, where they are highly expressed, and does not change the number of $\beta 3^{*}$ receptors in either region [116] notwithstanding the fact that $\alpha 6^{*}$ receptors contain the $\beta 3$ subunit in both $[67,83]$. This suggests that $\alpha 6 \beta 3 *$ receptors are more resistant to nicotine induced down-regulation than $\alpha 6(\operatorname{non} \beta 3)^{*}$ receptors, or that the $\beta 3^{*}$ receptors assemble with other $\alpha$ subunits.

It is not known why nicotine has such different effects on $\alpha 6^{*}$ receptors. In situ hybridisation and single-cell PCR studies have shown that there is a mixture of $\alpha 4, \alpha 6, \beta 2$ and $\beta 3$ subunits in midbrain dopaminergic neurons $[65,120]$. If the number of $\beta 2$ subunits is limited, it is possible that $\mathrm{nAChR}$ subunits compete for assembly in the endoplasmic reticulum of these neurons. By acting as a preferential chaperone on $\alpha 4 \beta 2$ receptors, nicotine may favour their formation and thus decrease the pool of $\beta 2$ subunits available for assembly with the $\alpha 6$ subunit (see also [118] for a similar hypothesis). In the case of the superior colliculus, it is not known whether the $\alpha 4$, $\alpha 6, \beta 2$ and $\beta 3$ subunits are present in the same retinal ganglionic cells, and so it is possible that there is no competition between $\alpha 4$ and $\alpha 6$ subunits.

The role of nAChR up-regulation in inducing and/or maintaining nicotine dependence is still uncertain. Up-regulation can be achieved in animals by means of administration routes that are different from those of smokers and/or as nicotine doses that are much higher. Yet, it has been shown that smokers have higher cortical levels of nicotinic agonist binding and $\alpha 4$ subunit than non-smokers [121, 122]. As the level of up-regulated subtypes persists for days after nicotine administration is stopped, it is possible that $\mathrm{nAChR}$ up-regulation plays a role during nicotine withdrawal. Decreased nicotine levels can allow nAChRs to recover from desensitisation and be more responsive to endogenous $\mathrm{ACh}$, which may contribute to withdrawal symptoms or craving. This possibility is also suggested by the results of neuroimaging studies showing that smokers have high $\beta 2 *$ receptor levels for at least seven days after stopping smoking [123]. The levels of $\beta 2 \mathrm{nAChRs}$ do not correlate with the severity of dependence or withdrawal, but only with the urge to smoke in order to relieve withdrawal symptoms.

The vast majority of the different effects of nicotine are determined by the functional features and location of the nAChR subtypes with which it interacts in specific neuronal circuits, but recent findings have shown that nicotine affects not only the number of nAChRs, but also that of 
other receptors and proteins important for the development of synaptic plasticity, either by partially blocking the proteosome, or through other mechanisms [98, 104, 124, 125]. It therefore seems that nicotine induces behavioural effects via a complex interplay of different signal transduction pathways that can be different in different nervous circuits.

\section{Conclusions}

The fine molecular structure of nAChRs has been better clarified over recent years mainly as a result of very different methodological approaches.

It has been shown that there is a substantial number of native subtypes, although native nAChRs are assembled into functional pentamers made up of a relatively restricted number of subunit combinations. Moreover, the in vivo characterisation of new and unsuspected subtypes (heteromeric $\alpha 7 \beta 2$ ) has increased the complexity of studying native subtypes.

Much has been learned concerning the role of accessory subunits in the function and pharmacology of the different subtypes, but we still do not know their precise role in $\mathrm{nAChR}$ localisation and traffic and the subunit stochiometry of the heteromeric subtypes remains a largely unsolved question.

Finally the mechanisms by which chronic nicotine affects the function and number of native subtypes are still elusive and this will be an important future step in our understanding of the role of nAChRs in tobacco dependence and neuropsychiatric diseases.

\section{Acknowledgements}

The paper was supported by Italian PRIN grant 20072BTSR2 to FC and MZ, and EC Neurocypres grant $\mathrm{n}^{\circ} 202088$ to $\mathrm{CG}$ and MZ, and grants from Fondazione Cariplo (2006/0779/109251) and Compagnia San Paolo (2005-1964) to CG.

Our special thanks go to Dr.Annalisa Gaimarri for drawing the figures. 


\section{Figure 1}

\section{nAChR subtypes in the habenula -interpeduncular pathway}

Upper panel: A simplified illustration of the habenulo-interpeduncular pathway highlighting its cholinergic (red) and non-cholinergic components (blue).

Lower panel: Subunit composition and putative stoichiometry of the main nAChR subtypes expressed in the presynaptic cholinergic ( $\alpha 3 \beta 4$ and $\alpha 3 \beta 3 \beta 4)$ and non-cholinergic $\left(\alpha 3 \beta 2^{*}\right)$ IPn terminals. The $\alpha 2 \beta 2^{*}$ and $\alpha 4 \beta 4^{*}$ receptors are localised on intrinsic IPn neurons, whereas the $\alpha 4 \beta 2^{*}$ subtype may have a presynaptic or postsynaptic localisation in the IPn. The proposed localisations are based on the results and references reported in [64]. 


\section{References}

[1] Picciotto MR, Caldarone BJ, Brunzell DH, Zachariou V, Stevens TR, King SL. Neuronal nicotinic acetylcholine receptor subunit knockout mice: physiological and behavioral phenotypes and possible clinical implications. Pharmacol Ther 2001;92:89-108.

[2] Gotti C, Clementi F. Neuronal nicotinic receptors: from structure to pathology. Prog Neurobiol 2004;74:363-96.

[3] Dani JA, Bertrand D. Nicotinic acetylcholine receptors and nicotinic cholinergic mechanisms of the central nervous system. Annu Rev Pharmacol Toxicol 2007;47:699-729.

[4] Albuquerque EX, Pereira EF, Alkondon M, Rogers SW. Mammalian nicotinic acetylcholine receptors: from structure to function. Physiol Rev 2009;89:73-120.

[5] Jensen AA, Frolund B, Liljefors T, Krogsgaard-Larsen P. Neuronal nicotinic acetylcholine receptors: structural revelations, target identifications, and therapeutic inspirations. J Med Chem 2005;48:4705-45.

[6] Fucile S. Ca2+ permeability of nicotinic acetylcholine receptors. Cell Calcium 2004;35:1-8.

[7] Dajas-Bailador F, Wonnacott S. Nicotinic acetylcholine receptors and the regulation of neuronal signalling. Trends Pharmacol Sci 2004;25:317-24.

[8] Alkondon M, Albuquerque EX. The nicotinic acetylcholine receptor subtypes and their function in the hippocampus and cerebral cortex. Prog Brain Res 2004;145:109-20.

[9] Champtiaux N, Changeux JP. Knock-out and knock-in mice to investigate the role of nicotinic receptors in the central nervous system. Curr Drug Targets CNS Neurol Disord 2002;1:319-30.

[10] Drago J, McColl CD, Horne MK, Finkelstein DI, Ross SA. Neuronal nicotinic receptors: insights gained from gene knockout and knockin mutant mice. Cell Mol Life Sci 2003;60:1267-80.

[11] Maskos U. Emerging concepts: novel integration of in vivo approaches to localize the function of nicotinic receptors. J Neurochem 2007;100:596-602.

[12] Fowler CD, Arends MA, Kenny PJ. Subtypes of nicotinic acetylcholine receptors in nicotine reward, dependence, and withdrawal: evidence from genetically modified mice. Behav Pharmacol 2008;19:461-84.

[13] Gotti C, Moretti M, Gaimarri A, Zanardi A, Clementi F, Zoli M. Heterogeneity and complexity of native brain nicotinic receptors. Biochem Pharmacol 2007;74:1102-11.

[14] Millar NS, Gotti C. Diversity of vertebrate nicotinic acetylcholine receptors. Neuropharmacology 2009;56:237-46. 
[15] Corringer PJ, Sallette J, Changeux JP. Nicotine enhances intracellular nicotinic receptor maturation: a novel mechanism of neural plasticity? J Physiol Paris 2006;99:162-71.

[16] Sine SM, Engel AG. Recent advances in Cys-loop receptor structure and function. Nature 2006;440:448-55.

[17] Wessler I, Kirkpatrick CJ. Acetylcholine beyond neurons: the non-neuronal cholinergic system in humans. Br J Pharmacol 2008.

[18] Schuller HM. Is cancer triggered by altered signalling of nicotinic acetylcholine receptors? Nat Rev Cancer 2009;9:195-205.

[19] Grando SA. Basic and clinical aspects of non-neuronal acetylcholine: biological and clinical significance of non-canonical ligands of epithelial nicotinic acetylcholine receptors. J Pharmacol Sci 2008;106:174-9.

[20] Egleton RD, Brown KC, Dasgupta P. Nicotinic acetylcholine receptors in cancer: multiple roles in proliferation and inhibition of apoptosis. Trends Pharmacol Sci 2008;29:151-8.

[21] Kawashima K, Fujii T. Basic and clinical aspects of non-neuronal acetylcholine: overview of non-neuronal cholinergic systems and their biological significance. J Pharmacol Sci 2008;106:167-73.

[22] Celie PH, Klaassen RV, van Rossum-Fikkert SE, van Elk R, van Nierop P, Smit AB, et al. Crystal structure of acetylcholine-binding protein from Bulinus truncatus reveals the conserved structural scaffold and sites of variation in nicotinic acetylcholine receptors. $\mathrm{J}$ Biol Chem 2005;280:26457-66.

[23] Celie PH, van Rossum-Fikkert SE, van Dijk WJ, Brejc K, Smit AB, Sixma TK. Nicotine and carbamylcholine binding to nicotinic acetylcholine receptors as studied in AChBP crystal structures. Neuron 2004;41:907-14.

[24] Hansen SB, Sulzenbacher G, Huxford T, Marchot P, Taylor P, Bourne Y. Structures of Aplysia AChBP complexes with nicotinic agonists and antagonists reveal distinctive binding interfaces and conformations. Embo J 2005;24:3635-46.

[25] Hilf RJ, Dutzler R. X-ray structure of a prokaryotic pentameric ligand-gated ion channel. Nature 2008;452:375-9.

[26] Hilf RJ, Dutzler R. Structure of a potentially open state of a proton-activated pentameric ligand-gated ion channel. Nature 2009;457:115-8.

[27] Bocquet N, Nury H, Baaden M, Le Poupon C, Changeux JP, Delarue M, et al. X-ray structure of a pentameric ligand-gated ion channel in an apparently open conformation. Nature 2009;457:111-4. 
[28] Unwin N. Refined structure of the nicotinic acetylcholine receptor at 4A resolution. J Mol Biol 2005;346:967-89.

[29] Giniatullin R, Nistri A, Yakel JL. Desensitization of nicotinic ACh receptors: shaping cholinergic signaling. Trends Neurosci 2005;28:371-8.

[30] Picciotto MR, Addy NA, Mineur YS, Brunzell DH. It is not "either/or": activation and desensitization of nicotinic acetylcholine receptors both contribute to behaviors related to nicotine addiction and mood. Prog Neurobiol 2008;84:329-42.

[31] Gotti C, Zoli M, Clementi F. Brain nicotinic acetylcholine receptors: native subtypes and their relevance. Trends Pharmacol Sci 2006;27:482-91.

[32] Elgoyhen AB, Vetter DE, Katz E, Rothlin CV, Heinemann SF, Boulter J. alpha10: a determinant of nicotinic cholinergic receptor function in mammalian vestibular and cochlear mechanosensory hair cells. Proc Natl Acad Sci U S A 2001;98:3501-6.

[33] Sgard F, Charpantier E, Bertrand S, Walker N, Caput D, Graham D, et al. A novel human nicotinic receptor subunit, alpha10, that confers functionality to the alpha9-subunit. Mol Pharmacol 2002;61:150-9.

[34] Ramirez-Latorre J, Yu CR, Qu X, Perin F, Karlin A, Role L. Functional contributions of alpha5 subunit to neuronal acetylcholine receptor channels. Nature 1996;380:347-51.

[35] Groot-Kormelink PJ, Luyten WH, Colquhoun D, Sivilotti LG. A reporter mutation approach shows incorporation of the "orphan" subunit beta3 into a functional nicotinic receptor. J Biol Chem 1998;273:15317-20.

[36] Corringer PJ, Le Novere N, Changeux JP. Nicotinic receptors at the amino acid level. Annu Rev Pharmacol Toxicol 2000;40:431-58.

[37] Kuryatov A, Onksen J, Lindstrom J. Roles of accessory subunits in alpha4beta2(*) nicotinic receptors. Mol Pharmacol 2008;74:132-43..

[38] Moroni M, Zwart R, Sher E, Cassels BK, Bermudez I. alpha4beta2 nicotinic receptors with high and low acetylcholine sensitivity: pharmacology, stoichiometry, and sensitivity to longterm exposure to nicotine. Mol Pharmacol 2006;70:755-68.

[39] Tapia L, Kuryatov A, Lindstrom J. Ca2+ permeability of the (alpha4)3(beta2)2 stoichiometry greatly exceeds that of (alpha4)2(beta2)3 human acetylcholine receptors. Mol Pharmacol 2007;71:769-76.

[40] Moroni M, Vijayan R, Carbone A, Zwart R, Biggin PC, Bermudez I. Non-agonist-binding subunit interfaces confer distinct functional signatures to the alternate stoichiometries of the alpha4beta2 nicotinic receptor: an alpha4-alpha4 interface is required for $\mathrm{Zn} 2+$ potentiation. J Neurosci 2008;28:6884-94. 
[41] Palma E, Maggi L, Barabino B, Eusebi F, Ballivet M. Nicotinic acetylcholine receptors assembled from the alpha7 and beta3 subunits. J Biol Chem 1999;274:18335-40.

[42] Broadbent S, Groot-Kormelink PJ, Krashia PA, Harkness PC, Millar NS, Beato M, et al. Incorporation of the beta3 subunit has a dominant-negative effect on the function of recombinant central-type neuronal nicotinic receptors. Mol Pharmacol 2006;70:1350-7.

[43] Drenan RM, Nashmi R, Imoukhuede P, Just H, McKinney S, Lester HA. Subcellular trafficking, pentameric assembly, and subunit stoichiometry of neuronal nicotinic acetylcholine receptors containing fluorescently labeled alpha6 and beta3 subunits. Mol Pharmacol 2008;73:27-41.

[44] Anand R, Conroy WG, Schoepfer R, Whiting P, Lindstrom J. Neuronal nicotinic acetylcholine receptors expressed in Xenopus oocytes have a pentameric quaternary structure. J Biol Chem 1991;266:11192-8.

[45] Cooper E, Couturier S, Ballivet M. Pentameric structure and subunit stoichiometry of a neuronal nicotinic acetylcholine receptor. Nature 1991;350:235-8.

[46] Zwart R, Vijverberg HP. Four pharmacologically distinct subtypes of alpha4beta2 nicotinic acetylcholine receptor expressed in Xenopus laevis oocytes. Mol Pharmacol 1998;54:112431.

[47] Nelson ME, Kuryatov A, Choi CH, Zhou Y, Lindstrom J. Alternate stoichiometries of alpha4beta2 nicotinic acetylcholine receptors. Mol Pharmacol 2003;63:332-41.

[48] Zhou Y, Nelson ME, Kuryatov A, Choi C, Cooper J, Lindstrom J. Human alpha4beta2 acetylcholine receptors formed from linked subunits. J Neurosci 2003;23:9004-15.

[49] Marks MJ, Whiteaker P, Collins AC. Deletion of the alpha7, beta2, or beta4 nicotinic receptor subunit genes identifies highly expressed subtypes with relatively low affinity for [3H] epibatidine. Mol Pharmacol 2006;70:947-59.

[50] Gotti C, Moretti M, Meinerz N, Clementi F, Gaimarri A, Collins AC, et al. Partial deletion of the nicotinic cholinergic receptor $\alpha 4$ or $\beta 2$ subunit genes changes the acetylcholine sensitivity of receptor mediated $86 \mathrm{Rb}^{+}$efflux in cortex and thalamus and alters relative expression of $\alpha 4$ and $\beta 2$ subunits. Mol Pharmacol 2008;73:1796-807.

[51] Son CD, Moss FJ, Cohen BN, Lester HA. Nicotine Normalizes Intracellular Subunit Stoichiometry of Nicotinic Receptors Carrying Mutations linked to Autosomal Dominant Nocturnal Frontal Lobe Epilepsy. Mol Pharmacol 2009.

[52] Millar NS. RIC-3: a nicotinic acetylcholine receptor chaperone. Br J Pharmacol 2008;153 Suppl 1:S177-83. 
[53] Millar NS, Harkness PC. Assembly and trafficking of nicotinic acetylcholine receptors (Review). Mol Membr Biol 2008;25:279-92.

[54] Girod R, Crabtree G, Ernstrom G, Ramirez-Latorre J, McGehee D, Turner J, et al. Heteromeric complexes of alpha 5 and/or alpha 7 subunits. Effects of calcium and potential role in nicotine-induced presynaptic facilitation. Ann N Y Acad Sci 1999;868:578-90.

[55] Khiroug SS, Harkness PC, Lamb PW, Sudweeks SN, Khiroug L, Millar NS, et al. Rat nicotinic ACh receptor alpha7 and beta2 subunits co-assemble to form functional heteromeric nicotinic receptor channels. J Physiol 2002;540:425-34.

[56] Lewis TM, Harkness PC, Sivilotti LG, Colquhoun D, Millar NS. The ion channel properties of a rat recombinant neuronal nicotinic receptor are dependent on the host cell type. $\mathrm{J}$ Physiol 1997;505 ( Pt 2):299-306.

[57] Sweileh W, Wenberg K, Xu J, Forsayeth J, Hardy S, Loring RH. Multistep expression and assembly of neuronal nicotinic receptors is both host-cell- and receptor-subtype-dependent. Brain Res Mol Brain Res 2000;75:293-302.

[58] Brown RW, Collins AC, Lindstrom JM, Whiteaker P. Nicotinic alpha5 subunit deletion locally reduces high-affinity agonist activation without altering nicotinic receptor numbers. $\mathrm{J}$ Neurochem 2007;103:204-15.

[59] Salas R, Orr-Urtreger A, Broide RS, Beaudet A, Paylor R, De Biasi M. The nicotinic acetylcholine receptor subunit alpha 5 mediates short-term effects of nicotine in vivo. Mol Pharmacol 2003;63:1059-66.

[60] Kedmi M, Beaudet AL, Orr-Urtreger A. Mice lacking neuronal nicotinic acetylcholine receptor beta4-subunit and mice lacking both alpha5- and beta4-subunits are highly resistant to nicotine-induced seizures. Physiol Genomics 2004;17:221-9.

[61] Han ZY, Le Novere N, Zoli M, Hill JA, Jr., Champtiaux N, Changeux JP. Localization of nAChR subunit mRNAs in the brain of Macaca mulatta. Eur J Neurosci 2000;12:3664-74.

[62] Han ZY, Zoli M, Cardona A, Bourgeois JP, Changeux JP, Le Novere N. Localization of $[3 \mathrm{H}]$ nicotine, $[3 \mathrm{H}]$ cytisine, $[3 \mathrm{H}]$ epibatidine, and [125I]alpha-bungarotoxin binding sites in the brain of Macaca mulatta. J Comp Neurol 2003;461:49-60.

[63] Moretti M, Vailati S, Zoli M, Lippi G, Riganti L, Longhi R, et al. Nicotinic Acetylcholine Receptor Subtypes Expression during Rat Retina Development and Their Regulation by Visual Experience. Mol Pharmacol 2004;66:85-96.

[64] Grady SR, Moretti M, Zoli M, Marks MJ, Zanardi A, Pucci L, et al. Rodent habenulointerpeduncular pathway expresses a large variety of uncommon nAChR subtypes, but only 
the alpha3beta4* and alpha3beta3beta4* subtypes mediate acetylcholine release. J Neurosci 2009;29:2272-82.

[65] Le Novere N, Zoli M, Changeux JP. Neuronal nicotinic receptor alpha 6 subunit mRNA is selectively concentrated in catecholaminergic nuclei of the rat brain. Eur $\mathrm{J}$ Neurosci 1996;8:2428-39.

[66] Cui C, Booker TK, Allen RS, Grady SR, Whiteaker P, Marks MJ, et al. The beta3 nicotinic receptor subunit: a component of alpha-conotoxin MII-binding nicotinic acetylcholine receptors that modulate dopamine release and related behaviors. J Neurosci 2003;23:1104553.

[67] Zoli M, Moretti M, Zanardi A, McIntosh JM, Clementi F, Gotti C. Identification of the nicotinic receptor subtypes expressed on dopaminergic terminals in the rat striatum. $\mathrm{J}$ Neurosci 2002;22:8785-9.

[68] Salminen O, Drapeau JA, McIntosh JM, Collins AC, Marks MJ, Grady SR. Pharmacology of \{alpha\}-Conotoxin MII-Sensitive Subtypes of Nicotinic Acetylcholine Receptors Isolated by Breeding of Null Mutant Mice. Mol Pharmacol 2007;71:1563-71.

[69] Perez XA, Parameswaran N, Huang LZ, O'Leary KT, Quik M. Pre-synaptic dopaminergic compensation after moderate nigrostriatal damage in non-human primates. J Neurochem 2008;105:1861-72.

[70] Maskos U, Molles BE, Pons S, Besson M, Guiard BP, Guilloux JP, et al. Nicotine reinforcement and cognition restored by targeted expression of nicotinic receptors. Nature 2005;436:103-7.

[71] Pons S, Fattore L, Cossu G, Tolu S, Porcu E, McIntosh JM, et al. Crucial role of alpha4 and alpha6 nicotinic acetylcholine receptor subunits from ventral tegmental area in systemic nicotine self-administration. J Neurosci 2008;28:12318-27.

[72] Avale ME, Faure P, Pons S, Robledo P, Deltheil T, David DJ, et al. Interplay of beta2* nicotinic receptors and dopamine pathways in the control of spontaneous locomotion. Proc Natl Acad Sci U S A 2008;105:15991-6.

[73] Drenan RM, Grady SR, Whiteaker P, McClure-Begley T, McKinney S, Miwa JM, et al. In vivo activation of midbrain dopamine neurons via sensitized, high-affinity alpha 6 nicotinic acetylcholine receptors. Neuron 2008;60:123-36.

[74] Exley R, Clements MA, Hartung H, McIntosh JM, Cragg SJ. Alpha6-containing nicotinic acetylcholine receptors dominate the nicotine control of dopamine neurotransmission in nucleus accumbens. Neuropsychopharmacology 2008;33:2158-66. 
[75] Bordia T, Grady SR, McIntosh JM, Quik M. Nigrostriatal damage preferentially decreases a subpopulation of alpha6beta2* nAChRs in mouse, monkey, and Parkinson's disease striatum. Mol Pharmacol 2007;72:52-61.

[76] Salas R, Pieri F, De Biasi M. Decreased signs of nicotine withdrawal in mice null for the beta4 nicotinic acetylcholine receptor subunit. J Neurosci 2004;24:10035-9.

[77] Salas R, Sturm R, Boulter J, De Biasi M. Nicotinic receptors in the habenulointerpeduncular system are necessary for nicotine withdrawal in mice. J Neurosci 2009;29:3014-8.

[78] Glick SD, Ramirez RL, Livi JM, Maisonneuve IM. 18-Methoxycoronaridine acts in the medial habenula and/or interpeduncular nucleus to decrease morphine self-administration in rats. Eur J Pharmacol 2006;537:94-8.

[79] Taraschenko OD, Shulan JM, Maisonneuve IM, Glick SD. 18-MC acts in the medial habenula and interpeduncular nucleus to attenuate dopamine sensitization to morphine in the nucleus accumbens. Synapse 2007;61:547-60.

[80] Zoli M, Lena C, Picciotto MR, Changeux JP. Identification of four classes of brain nicotinic receptors using beta2 mutant mice. J Neurosci 1998;18:4461-72.

[81] Whiteaker P, Peterson CG, Xu W, McIntosh JM, Paylor R, Beaudet AL, et al. Involvement of the alpha3 subunit in central nicotinic binding populations. J Neurosci 2002;22:2522-9.

[82] Marks MJ, Whiteaker P, Grady SR, Picciotto MR, McIntosh JM, Collins AC. Characterization of [(125) I]epibatidine binding and nicotinic agonist-mediated (86) $\mathrm{Rb}(+)$ efflux in interpeduncular nucleus and inferior colliculus of beta2 null mutant mice. J Neurochem 2002;81:1102-15.

[83] Gotti C, Moretti M, Zanardi A, Gaimarri A, Champtiaux N, Changeux JP, et al. Heterogeneity and selective targeting of neuronal nicotinic acetylcholine receptor (nAChR) subtypes expressed on retinal afferents of the superior colliculus and lateral geniculate nucleus: identification of a new native nAChR subtype alpha3beta2(alpha5 or beta3) enriched in retinocollicular afferents. Mol Pharmacol 2005;68:1162-71.

[84] Champtiaux N, Gotti C, Cordero-Erausquin M, David DJ, Przybylski C, Lena C, et al. Subunit composition of functional nicotinic receptors in dopaminergic neurons investigated with knock-out mice. J Neurosci 2003;23:7820-9.

[85] Conroy WG, Berg DK. Neurons can maintain multiple classes of nicotinic acetylcholine receptors distinguished by different subunit compositions. J Biol Chem 1995;270:4424-31.

[86] Klemm WR. Habenular and interpeduncularis nuclei: shared components in multiplefunction networks. Med Sci Monit 2004;10:RA261-73. 
[87] Lecourtier L, Kelly PH. A conductor hidden in the orchestra? Role of the habenular complex in monoamine transmission and cognition. Neurosci Biobehav Rev 2007;31:65872.

[88] Phillipson OT, Pycock CJ. Dopamine neurones of the ventral tegmentum project to both medial and lateral habenula. Some implications for habenular function. Exp Brain Res 1982;45:89-94.

[89] Meshul CK, Noguchi K, Emre N, Ellison G. Cocaine-induced changes in glutamate and GABA immunolabeling within rat habenula and nucleus accumbens. Synapse 1998;30:21120.

[90] Li T, Gao W, Rao ZR. Noxious somatic stimulation-induced expression of Fos-like immunoreactivity in catecholaminergic neurons with habenular nucleus projection in the medullary visceral zone of rat. Brain Res 1998;783:51-6.

[91] Wada E, Wada K, Boulter J, Deneris E, Heinemann S, Patrick J, et al. Distribution of alpha 2, alpha 3, alpha 4, and beta 2 neuronal nicotinic receptor subunit mRNAs in the central nervous system: a hybridization histochemical study in the rat. J Comp Neurol 1989;284:314-35.

[92] Dickinson JA, Kew JN, Wonnacott S. Presynaptic alpha 7- and beta 2-containing nicotinic acetylcholine receptors modulate excitatory amino acid release from rat prefrontal cortex nerve terminals via distinct cellular mechanisms. Mol Pharmacol 2008;74:348-59.

[93] Quarta D, Naylor CG, Barik J, Fernandes C, Wonnacott S, Stolerman IP. Drug discrimination and neurochemical studies in alpha7 null mutant mice: tests for the role of nicotinic alpha7 receptors in dopamine release. Psychopharmacology (Berl) 2009;203:399410.

[94] Livingstone PD, Srinivasan J, Kew JN, Dawson LA, Gotti C, Moretti M, et al. alpha7 and non-alpha7 nicotinic acetylcholine receptors modulate dopamine release in vitro and in vivo in the rat prefrontal cortex. Eur J Neurosci 2009;29:539-50.

[95] Barik J, Wonnacott S. Indirect modulation by alpha7 nicotinic acetylcholine receptors of noradrenaline release in rat hippocampal slices: interaction with glutamate and GABA systems and effect of nicotine withdrawal. Mol Pharmacol 2006;69:618-28.

[96] Liu Q, Huang Y, Xue F, Simard A, DeChon J, Li G, et al. A novel nicotinic acetylcholine receptor subtype in basal forebrain cholinergic neurons with high sensitivity to amyloid peptides. J Neurosci 2009;29:918-29.

[97] Buisson B, Bertrand D. Nicotine addiction: the possible role of functional upregulation. Trends Pharmacol Sci 2002;23:130-6. 
[98] Perry DC, Davila-Garcia MI, Stockmeier CA, Kellar KJ. Increased nicotinic receptors in brains from smokers: membrane binding and autoradiography studies. J Pharmacol Exp Ther 1999;289:1545-52.

[99] Marks MJ, Pauly JR, Gross SD, Deneris ES, Hermans-Borgmeyer I, Heinemann SF, et al. Nicotine binding and nicotinic receptor subunit RNA after chronic nicotine treatment. J Neurosci 1992;12:2765-84.

[100] Nashmi R, Lester H. Cell autonomy, receptor autonomy, and thermodynamics in nicotine receptor up-regulation. Biochem Pharmacol 2007;74:1145-54.

[101] Walsh H, Govind AP, Mastro R, Hoda JC, Bertrand D, Vallejo Y, et al. Up-regulation of nicotinic receptors by nicotine varies with receptor subtype. J Biol Chem 2008;283:6022-32.

[102] Tumkosit P, Kuryatov A, Luo J, Lindstrom J. Beta3 subunits promote expression and nicotine-induced up-regulation of human nicotinic alpha6* nicotinic acetylcholine receptors expressed in transfected cell lines. Mol Pharmacol 2006;70:1358-68.

[103] Xiao Y, Kellar KJ. The comparative pharmacology and up-regulation of rat neuronal nicotinic receptor subtype binding sites stably expressed in transfected mammalian cells. J Pharmacol Exp Ther 2004;310:98-107.

[104] Nguyen HN, Rasmussen BA, Perry DC. Binding and functional activity of nicotinic cholinergic receptors in selected rat brain regions are increased following long-term but not short-term nicotine treatment. J Neurochem 2004;90:40-9.

[105] Sallette J, Pons S, Devillers-Thiery A, Soudant M, Prado de Carvalho L, Changeux JP, et al. Nicotine upregulates its own receptors through enhanced intracellular maturation. Neuron 2005;46:595-607.

[106] Gaimarri A, Moretti M, Riganti L, Zanardi A, Clementi F, Gotti C. Regulation of neuronal nicotinic receptor traffic and expression. Brain Res Rev 2007;55:134-43.

[107] Mao D, Perry DC, Yasuda RP, Wolfe BB, Kellar KJ. The alpha4beta2alpha5 nicotinic cholinergic receptor in rat brain is resistant to up-regulation by nicotine in vivo. J Neurochem 2008;104:446-56.

[108] Rasmussen BA, Perry DC. An autoradiographic analysis of [125I]alpha-bungarotoxin binding in rat brain after chronic nicotine exposure. Neurosci Lett 2006;404:9-14.

[109] Olale F, Gerzanich V, Kuryatov A, Wang F, Lindstrom J. Chronic nicotine exposure differentially affects the function of human alpha3, alpha4, and alpha7 neuronal nicotinic receptor subtypes. J Pharmacol Exp Ther 1997;283:675-83. 
[110] Kawai H, Berg DK. Nicotinic acetylcholine receptors containing alpha 7 subunits on rat cortical neurons do not undergo long-lasting inactivation even when up-regulated by chronic nicotine exposure. J Neurochem 2001;78:1367-78.

[111] $\mathrm{Yu} \mathrm{ZJ,} \mathrm{Wecker} \mathrm{L.} \mathrm{Chronic} \mathrm{nicotine} \mathrm{administration} \mathrm{differentially} \mathrm{affects} \mathrm{neurotransmitter}$ release from rat striatal slices. J Neurochem 1994;63:186-94.

[112] Marks MJ, Farnham DA, Grady SR, Collins AC. Nicotinic receptor function determined by stimulation of rubidium efflux from mouse brain synaptosomes. J Pharmacol Exp Ther $1993 ; 264: 542-52$.

[113] Grilli M, Parodi M, Raiteri M, Marchi M. Chronic nicotine differentially affects the function of nicotinic receptor subtypes regulating neurotransmitter release. J Neurochem 2005;93:1353-60.

[114] Parker SL, Fu Y, McAllen K, Luo J, McIntosh JM, Lindstrom JM, et al. Up-regulation of brain nicotinic acetylcholine receptors in the rat during long-term self-administration of nicotine: disproportionate increase of the alpha6 subunit. Mol Pharmacol 2004;65:611-22.

[115] Mugnaini M, Garzotti M, Sartori I, Pilla M, Repeto P, Heidbreder CA, et al. Selective down-regulation of [(125)I]YY0-alpha-conotoxin MII binding in rat mesostriatal dopamine pathway following continuous infusion of nicotine. Neuroscience 2006;137:565-72.

[116] Perry DC, Mao D, Gold AB, McIntosh JM, Pezzullo JC, Kellar KJ. Chronic nicotine differentially regulates alpha6- and beta3-containing nicotinic cholinergic receptors in rat brain. J Pharmacol Exp Ther 2007;322:306-15.

[117] Lai A, Parameswaran N, Khwaja M, Whiteaker P, Lindstrom JM, Fan H, et al. Long-term nicotine treatment decreases striatal alpha $6^{*}$ nicotinic acetylcholine receptor sites and function in mice. Mol Pharmacol 2005;67:1639-47.

[118] Perez XA, Bordia T, McIntosh JM, Grady SR, Quik M. Long-term nicotine treatment differentially regulates striatal alpha6alpha4beta2* and alpha6(nonalpha4)beta2* nAChR expression and function. Mol Pharmacol 2008;74:844-53.

[119] Perez XA, O'Leary KT, Parameswaran N, McIntosh JM, Quik M. Prominent role of alpha3/alpha6beta2* nAChRs in regulating evoked dopamine release in primate putamen: effect of long-term nicotine treatment. Mol Pharmacol 2009;75:938-46.

[120] Klink R, de Kerchove d'Exaerde A, Zoli M, Changeux JP. Molecular and physiological diversity of nicotinic acetylcholine receptors in the midbrain dopaminergic nuclei. $\mathrm{J}$ Neurosci 2001;21:1452-63. 
[121] Martin-Ruiz CM, Court JA, Molnar E, Lee M, Gotti C, Mamalaki A, et al. Alpha4 but not alpha3 and alpha7 nicotinic acetylcholine receptor subunits are lost from the temporal cortex in Alzheimer's disease. J Neurochem 1999;73:1635-40.

[122] Brasic JR, Zhou Y, Musachio JL, Hilton J, Fan H, Crabb A, et al. Single photon emission computed tomography experience with (S)-5-[(123)I]iodo-3-(2-azetidinylmethoxy)pyridine in the living human brain of smokers and nonsmokers. Synapse 2009;63:339-58.

[123] Staley JK, Krishnan-Sarin S, Cosgrove KP, Krantzler E, Frohlich E, Perry E, et al. Human tobacco smokers in early abstinence have higher levels of beta2* nicotinic acetylcholine receptors than nonsmokers. J Neurosci 2006;26:8707-14.

[124] Rezvani K, Teng Y, Shim D, De Biasi M. Nicotine regulates multiple synaptic proteins by inhibiting proteasomal activity. J Neurosci 2007;27:10508-19.

[125] Wang F, Chen H, Steketee JD, Sharp BM. Upregulation of ionotropic glutamate receptor subunits within specific mesocorticolimbic regions during chronic nicotine selfadministration. Neuropsychopharmacology 2007;32:103-9. 